\title{
Sarbanes-Oxley Act Of 2002 And Non-Profit Organizations
}

RamMohan R. Yallapragada, Fayetteville State University, USA C. William Roe, Arkansas State University, USA

Alfred G. Toma, University of Louisiana, Lafayette, USA

\begin{abstract}
The United States (US) has the unique record of having the largest sector of Non-Profit Organizations (NPO) in the world, comprising of over one million NPOs. The participation of Americans in philanthropic activities is unparalleled in the world. In recent years, NPOs received over $\$ 1.5$ trillion in revenues as reported by the Internal Revenue Service. These charitable organizations contribute immensely towards improving the lives of disadvantageous people. However, the huge NPO sector of our economy has been plagued recently with a deluge of corporate financial scandals similar to the scandals in corporations in the for-profit sector, such as Enron, WorldCom and Tyco. The misappropriations of funds involved over 150 NPOs, including world renowned organizations such as Red Cross and United Way. The embezzled funds amounted to over $\$ 1$ billion. The US Congress reacted quickly and vehemently to such scandals in the for-profit corporations with the enactment of Sarbanes-Oxley Act of 2002 (SOX), with far reaching consequences to the American business organizations. The rigorous provisions of SOX did not extend to Non-Profit Organizations except in two specific areas - whistleblower protection and retention of documents for verification. However, the present flood of NPO scandals triggered a bevy of SOX-like proposals for laws for Non-Profit Organizations as well, in the US Congress and in many state legislatures. Some states have already passed such laws. This paper presents a brief description of the NPO scandals, the ongoing proposals of SOX-like laws for NPOs in several states and their impact on the future governance of the NPOs.
\end{abstract}

Keywords: Sarbanes-Oxley Act of 2002, United States, Financial scandals, Large corporations, Non-profit organizations, American philanthropy, Fraud in charitable organizations, Sox-like proposals, State legislatures, US Congress

\section{BACKGROUND}

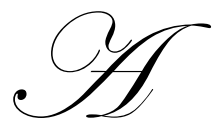

ccounting scandals of biblical proportions involving high-profile companies such as Enron, WorldCom, Global Crossing, Arthur Anderson etc., hit the United States (US) in late 2001 and early 2002, causing lot of confusion and distrust in the US financial markets. On June 18, 2002, the Senate Banking Committee passed a bill (\#2673), a draconian piece of legislation crafted by senator Paul Sarbanes (D-MD). Sarbanes - Oxley Act of 2002 (Sarbox or SOX), also known as Public Company Accounting Reform and Investor Protection Act Of 2002, was intended to provide a proper accounting framework and rules for public companies. It was passed in order to reinforce investment confidence and protect investors by improving the accuracy and reliability of corporate disclosure. It is also intended to "deter and punish corporate and accounting fraud and corruption, ensure justice for wrongdoers, and protect the interests of workers and shareholders" (Quote: President Bush). Without doubt, the Sarbanes-Oxley Act is the single most important piece of legislation affecting corporate governance, financial disclosure and the practice of public accounting since the US securities laws of the early 1930s. 


\section{IMPORTANT PROVISIONS AND CRIMINAL PENALTIES UNDER SOX}

Under one of the main provisions of SOX, the CEO and CFO of each issuer shall prepare a statement to accompany the audit report to certify the "appropriateness of the financial statements and disclosures contained in the periodic report, and that those financial statements and disclosures fairly present, in all material respects, the operations and financial condition of the issuer." . Any CEO or CFO who "recklessly" violates his or her certification of the company's financial statements would face penalties of fine of up to $\$ 1,000,000$ and/or up to 10 years imprisonment. If the violation is "willful", the fine goes up to $\$ 5,000,000$ and/or up to 20 years imprisonment.

Employees of issuers and accounting firms are extended "whistleblower protection" that would prohibit the employer from taking certain actions against employees who lawfully disclose private employer information to, among others, parties in a judicial proceeding involving a fraud claim. Whistle blowers are also granted a remedy of special damages and attorney's fees.

Sox makes it a crime for any person to corruptly alter, destroy, mutilate, or conceal any document with the intent to impair the object's integrity or availability for use in an official proceeding or to otherwise obstruct, influence or impede any official proceeding is liable for up to 20 years in prison and a fine or both.

\section{SCANDALS IN NONPROFIT SECTOR}

Recently, Americans are finding that the humongous financial scandals and fraud are not an exclusive property of public sector corporations alone. As Jackson (2006) States, Enron, WorldCom, and other corporate scandals may have led to the passage of Sarbanes-Oxley Act of 2002, but clearly the private sector does not have the corner on duplicity.

In recent years, scandals involving high-profile nonprofit organizations attracted public's attention much more than did the notorious scandals in their public sector counterparts such as Enron, WorldCom, Tyco etc. One of the scandals involved the Red Cross, following the 9/11/2001 terrorist attack. Millions of donors poured money into Red Cross to help the victims of 9/11 but, Red Cross diverted most of those donated funds to their other operations. Another scandal involved United Way in the Washington D. C. area where the CEO took $\$ 1.5$ million in questionable payments. When the scandal became public in 2002, donations to local charities dropped $60 \%$ from $\$ 45$ million to $\$ 18$ million (Mead, 2008). In 2002, the United Way, Lansing Michigan chapter was embezzled to the tune of $\$ 2$ million by the senior management.

There were many other nonprofits scandals during the same period A huge scandal at the world's largest environmental organization, The Nature Conservancy, involved land deals that illegally benefited insiders. In California, a Hollywood fundraiser pleaded guilty to diverting $\$ 7$ million of charitable donations to himself and his associates. News media reported that during the same period of the Enron etc. scandals, a total loss of $\$ 1.28$ billion has accrued to nonprofits due to malfeasance by management. Public trust in nonprofits took a nose dive due to these scandals. (Mead, 2008).

\section{SOX AND NON-PROFIT ORGANIZATIONS}

One of the impacts of Sarbanes-Oxley on Private \& Nonprofit companies, is that these organizations are continuing to adopt aspects of the Sarbanes-Oxley Act as a set of best practices, despite the fact that Congress never intended the Act to apply to non-public companies. These organizations are consistently self-imposing SarbanesOxley standards and have been more aggressive in their adoption of corporate governance reforms than their private for-profit counterparts.

Two of Sox provisions already apply to nonprofits as well. The first, known as the "whistle blower" provision, states that an organization cannot punish employees who report suspected illegal activities within the organization, and requires that companies establish procedures for handling complaints about accounting and financial matters. The second one states that organizations must not destroy, alter, or falsify documents and records to prevent their use in federal investigations and bankruptcy cases. (Williams, 2006). SOX makes it a criminal 
offence to knowingly retaliate against whistle blowers who have reported accurate information about institutional wrongdoing to officers of the law (Anft, 2008). O'Riely (2008) observes that almost all nonprofit health care organizations have since incorporated these two mandatory provisions.

Even though SOX requires all nonprofits to comply with only these two provisions, many nonprofits nowadays are choosing suo motu to adopt new, tougher internal policies in accountability and financial areas, under pressure from donors and board members (Jackson and Fogarty, 2006).

\section{LEGISLATION AND OTHER REFORMS FOR NONPROFITS}

As Mead (2008) States, since the advent of SOX, many states are considering (MA, MI, MS, NY, OH, PA, $\mathrm{VT}$ ) or have already passed (CA, CT, $\mathrm{NH}, \mathrm{WV})$ laws of their own corporate reforms for nonprofits. In many states, the nonprofits themselves are simultaneously undertaking voluntary reforms, mainly to obviate more stringent, mandatory reforms. Many nonprofits want to adopt reforms requiring CEO/CFO officer-certification of financial statements, similar to the requirements of SOX for public sector companies. An umbrella organization of over 500 nonprofits, under the name of, "The Independent Sector," was formed with a mission to, "lead, strengthen, and mobilize the charitable community in order to fulfill their vision of a just and inclusive society and a healthy democracy" (Mead, 2008). A Panel on the Nonprofit Sector, sponsored by the Independent Sector, recommended that the CEO or CFO of a nonprofit signs the IRS Form \#990 Statements, under penalty of perjury, to attest that they are true, correct, and complete (Mead, 2008). Form \#990 is a statement of certain financial information that all nonprofits must file with the IRS.

\section{REFORMS IN NONPROFIT HOSPITALS}

Policy makers and legislatures are beginning to be particularly concerned about the governance of many nonprofit hospitals. Many recent investigations of charity hospitals revealed lax governance activities. Violations included excessive executive compensations, inadequate charity care, and deceptive pricing of services. Many law suits against charity hospitals involved aggressive billing and collection practices, in violation of their charitable obligations to federal, state and local governments. Both houses of Congress recently conducted hearings on financial malfeasance of charity hospitals (Alexander, et al, 2008). Consequently, several federal and state initiatives similar to those of SOX were started to strengthen governance of nonprofit hospitals. These initiatives seek three main objectives:

1. Enhance independence of governing boards from senior management

2. Increase board accountability to community and donors

3. Reduce conflicts of interest between board members and the organization they govern.

Several states such as New Hampshire and New York have already passed similar legislation. At the federal level, IRS announced that it will increase its monitoring of tax-exempt charity and nonprofit hospitals with closer examinations of their hospital governance procedures (Alexander, et al, 2008)

\section{SOX AND HIGHER EDUCATION INSTITUTIONS}

SOX legislation explicitly excluded nonprofits from the implementation of its provisions (with two exceptions). However, "the huge splash that SOX has made has left the boards of some colleges and universities bobbing on a sea of uncertainty" (Dreier, Alexander, 2005). Trustees and lawmakers alike have been wondering whether to apply SOX provisions to higher education institutions and, if so, how to apply them to non profit colleges and universities.

According to Logue (2007), it makes sense to implement key elements of SOX in the areas of higher education too, so that colleges and universities can show students, parents, and donors that they are committed to transparency, accountability, and avoiding conflicts of interest. For instance, Georgia Tech, Berea College, and University of North Carolina System, are some of the higher education institutions which have voluntarily adopted some of the provisions of SOX in their governance policies. They believe in the opinion expressed by Jackson 
(2007) that, "donors and other stakeholders want evidence that their money is being used as they intended. They want to see return on their donations."

\section{SUMMARY, CONCLUSION, AND SUGGESTION FOR FUTURE RESEARCH}

The SOX law of 2002 was enacted mainly to eliminate the possibility of corporate fraud perpetrated by public sector companies, and to improve their governance and accountability.

It did not apply to private and nonprofit organizations, except in two provisions. However, after a spate of recent malfeasance and outright fraud in many high-visibility nonprofits such as Red Cross and United Way, federal and state legislatures started to consider extending SOX-like provisions to nonprofits as well. Many nonprofits have also started to voluntarily adopt many of the SOX provisions in their organizations. Non profits play a very important role in improving the quality of millions of Americans. The only life line for nonprofits is charitable donations by the American public, who are very generous by nature. If the nonprofits lose the public's trust and credibility it will lead to drying up of the main sources of donations. Extending SOX-like reforms to nonprofits would result in continued inflows of donations and also ensure that donations are not subjected to misappropriations and management malfeasance.

Further research is needed to explore the impact of the SOX provisions on whistle blowing and the successful implementation thereof in both public and private nonprofit organizations.

\section{AUTHOR INFORMATION}

Dr. RamMohan R. Yallapragada is an Associate Professor of Accounting at Fayetteville State University. He obtained his PhD degree in Accounting from the University of Houston. He holds a CPA certificate from the State of Louisiana. He taught at University of Texas at San Antonio, Nicholls State University, and University of Louisiana, Lafayette before joining FSU. He has published in several journals including Journal of Business and Economic Research, International Business and Economic Research Journal, Journal of Accounting and Finance Research, and Clarion Business and Economic Review. His research areas include Cost Accounting in Healthcare, Accounting irregularities in Fannie Mae, impact of Sarbanes-Oxley Act of 2002 on American corporations and the effect of unprecedented growth in the economies of India and China on global trade.

Alfred G. Toma holds the degrees of M.B.A. from the American University of Beirut, Lebanon and M.Sc in Marketing from Louisiana State University, Baton Rouge. He has co-authored journal articles and/or conference papers in the areas of International Business and Entrepreneurship. He currently teaches courses in International Business Management, Entrepreneurship, and Human Resources Management at the University of Louisiana at Lafayette. His extensive actual business works and consultancy experiences are focused on the areas of entry and operations in Middle East markets and entrepreneurial ventures start-ups.

C. William Roe received his doctorate from Mississippi State University in Management. He has authored/coauthored numerous journal articles and/or conference papers in management, marketing, healthcare administration and international business. He currently serves as Associate Dean and Director of Graduate Business Programs at Arkansas State University. He has consulted extensively with numerous public, private, for-profit, and not-forprofit organizations in the areas of strategic planning, leadership, organizational change and development and management development.

\section{REFERENCES}

1. Alexander, Jeffrey A. (2008). "Governance and Community Benefit: Are Hospitals Good Candidates For Sarbanes-Oxley type Reforms?” Journal of Health Politics, Vol. 33, Issue 2, April 2008, pp.199-224.

2. Anft, Michael (2008). "Charitables Urged To Do More To Protect Their Own Whistle Blowers," Chronicle Of Philanthropy, Vol. 20, Issue 23, September 18, 2008, p.15.

3. Dreier, Alexander E. (2005). "Sarbanes-Oxley And College Accountability," Chronicle Of Higher Education, Vol. 51, Issue 41, July 8, 2005, pp. 810-11. 
4. Jackson, Peggy M. (2007), Sarbanes-Oxley For Nonprofit Boards: A New Governance Paradigm, John Wiley and Sons, Hoboken, NJ, 2007.

5. Jackson, Peggy M. and Tony E. Fogarty (2006). "Sarbanes-Oxley And Non-Profit Management Skills, Techniques, Methods," Chronicle Of Philanthropy, Vol. 18, Issue 24, April 20, 2006, p. 29.

6. Logue, Ann C. (2007). "Best Foot Forward: SOX And Financial Standards," University Business, Vol. 10, Issue 7, July 2007, pp. 76-79.

7. Mead, Joseph (2008). "Confidence In Nonprofit Sector Through Sarbanes-Oxley Style Reforms," Michigan Law Review, Vol. 106, Issue 5, March 2008, pp.881-900.

8. O'Reilly, Eileen D. (2008). "Put Your Board On High Alert For Sarbanes-Oxley Creep", Hospitals \& Health Networks, Vol. 82, Issue 4, April 2008, pp. 57-60.

9. Williams, Grant (2006). "A New Report Sheds Light On Nonprofit-Accountability Practices," Chronicle Of Philanthropy, Vol. 18, Issue 24, September 28, 2006, p. 16. 
NOTES 